\title{
EFFECT OF TEMPERATURE ON YIELD AND SOME AGRONOMIC CHARACTERS OF SPRING WHEAT (Triticum aestivum L.) GENOTYPES
}

\author{
Akbar Hossain ${ }^{*}$, M.A.Z Sarker², M.A Hakim³, M.V. Lozovskaya4 ${ }^{4}$ and V.P. Zvolinsky5 \\ Received 28 September 2011, Revised 21 December 2011, Accepted 25 December 2011, Published online 31 December 2011
}

\begin{abstract}
Eight modern wheat varieties (viz., Sourav, Gourab, Shatabdi, Sufi, Bijoy, Prodip, BARI Gom-25 and BARI Gom-26) were evaluated to find out the suitable variety for optimum and late sown condition, to find out heat tolerant and heat sensitive variety and to find out the optimum sowing time for a specific variety. The experiment was conducted in the research

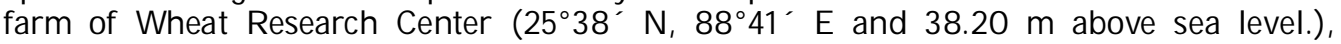
Bangladesh, under eight sowing times (viz., 8 Nov., 15 Nov., 22 Nov., 29 Nov., 6 Dec., 13 Dec., 20 Dec. and 27 Dec.). Results showed that wheat sown in November 22 to December 20 was significantly better compared to November 08, 15 and December 27, from the studied aspects of yield and yield components. Considering overall sowing performance of all genotypes Shatabdi is the best, followed by BARI Gom-26 (2nd), Sourav (3rd), Prodip (4th), Bijoy (5th), Gourab (6th), Sufi (7th) and BARI Gom-25 (least). In extremely heat stress (November 08 and December 27) condition Prodip was found to be heat sensitive genotype (yield reduction 41.18 and 28.92\%), followed by BARI Gom-26 (yield reduction 41.15 and $22.73 \%$ ). Both in too early and very late heat stress conditions, genotypes Sourav and BARI Gom-25 were found to be heat tolerant. In very early (November 08), variety Sourav (yield reduction 20.47\%) is recommended, followed by BARI Gom-25 (yield reduction 27.91\%) and in very late (December 27), Sufi is the best (yield reduction $8.60 \%$ ), followed by Bijoy (yield reduction 11.05\%).
\end{abstract}

Keywords: Wheat, Temperature, Genotypes, Yield and Agronomic Characters

${ }^{1,2,3}$ Wheat Research Center, Bangladesh Agricultural Research Institute, Bangladesh; ${ }^{4}$ Institute of Biological Resources, Astrakhan State University, Astrakhan, Russia; ${ }^{5}$ State Scientific Institute "The Caspian Scientific Research Institute of Arid Agriculture" of the Russian Academy of Agricultural Sciences, Salt Zaymishche, Chernoyarsky district, Astrakhan, Russia.

*Corresponding author's email: tanjimar2003@yahoo.com

Reviewed by Liton Chandra Sen, Montpellier SupAgro, France

\section{Introduction}

Wheat (Triticum aestivum L.) is the most important cereal crop in the world and is a major source of nourishment. In Bangladesh, it is the second major cereal crop after rice. Optimum time for sowing of wheat in Bangladesh is between mid November and first week of December (Hossain and Alam, 1986), due to its own definite requirements for temperature and light for emergence, growth and flowering (Dabre et al., 1993). But, about $85 \%$ of the total wheat area follows previous rice crop (Saunders, 1991) and over $60 \%$ of the total wheat crop is cultivated at late sowing conditions (Badruddin et al., 1994). In the north-western part of the country, where high lands generally remain fallow after aus rice or jute cultivation, seeding of wheat can be done in early November (heat stress condition). In some areas where wheat is followed by transplant aman rice or soil remains wet due to excessive rainfall, seeding is continued up to January (heat stress condition) (BARI, 2006).

Too early sowing produces weak plants with poor root systems. Temperature above optimum leads to irregular germination and the embryo frequently dies and the endosperm may under go decomposition due to activities of bacteria or fungi. In late planting the wheat variety should be short duration that may escape from high temperature at the grain filling stage (Phadnawis and Saini, 1992). Ansary et al. (1989) reported that delay sowing suppressed the yield, caused by reduction in the yield contributing traits like number of tillers, number of grains spike ${ }^{-1}$ and grain yield. Rajput and Verma, (1994) observed that normal sowing gave higher grain yield than late sowing. Early sowing always produces higher yield than late sowing. Each day delay in sowing from 20th November decreases grain yield @ 39 $\mathrm{kg} \mathrm{ha}^{-1}$ per day (Singh and Uttam, 1999). Ahmed (1986) also reported that about $1.3 \%$ reduction in 
grain yield occurs for each day delay after the first day of December. The adverse effect of temperature could be minimized by adjusting sowing time to an optimum date and to find out heat tolerant genotypes, which are suitable for late and very early sown conditions to ensure high grain yield.

Recently, some advanced wheat genotypes were released as varieties by Wheat Research Center of Bangladesh Agricultural Research Institute. These varieties were developed for optimum as well as late sown condition i.e., these genotypes have some heat tolerant characteristics (WRC, 2007). The newly developed varieties need to be evaluated for their agronomic performance under different environmental conditions. The present study was therefore, undertaken to evaluate the performance of newly released varieties under different heat stress condition, to find out the suitable variety for optimum and late sown condition, to find out heat tolerant and heat sensitive variety and to find out the optimum sowing time for a specific variety.

\section{Materials and Methods}

The experiment was carried out during November, 2009 to April, 2010 wheat season in the research field of Wheat Research Center (WRC) of Bangladesh Agricultural Research Institute (BARI), Bangladesh. The area is under Old Himalayan Piedmont Plain designated by Agro Ecological Zone-1. The geographical position of the area is between $25^{\circ} 38^{\prime} \mathrm{N}, 88^{\circ} 41^{\prime} \mathrm{E}$ and $38.20 \mathrm{~m}$ above sea level. The soil is sandy-loam and reaction is strongly acidic ( $\mathrm{pH}$ ranges from 4.5 to 5.5) (WRC, 2007). The organic matter content of the soil is about $1.0 \%$ (Bodruzzaman, et al., 2005).

The experiment was laid out in split-plot design with 3 replications. The main plots were assigned by 8 sowing dates viz., Nov. 08, Nov. 15, Nov. 22, Nov. 29, Dec. 06, Dec. 13, Dec. 20 and Dec. 27.
The sub-plots were assigned by 8 varieties viz., Sourav, Gourab, Shatabdi, Sufi, Bijoy, Prodip, BARI Gom-25 and BARI Gom-26. Unit plot size was $1.6 \times 4 \mathrm{~m}$. Before sowing, seeds were treated with Provax-200 WP an effective seed treating fungicide containing of Carboxin and Thiram. Seeds were sown at $120 \mathrm{~kg} \mathrm{ha}^{-1}$ in lines $20 \mathrm{~cm}$ apart. Recommended fertilizer doses, 100-27-4020-1 kgha-1 of N-P-K-S-B respectively, were applied. Irrigations were applied at crown root initiation, booting and grain filling stages. Intercultural operations were done properly according to treatments. The crop was harvested plot wise at full maturity. The harvested area for each plot was $3 \times 1.2 \mathrm{~m}$ (3m long 6 middle rows), for avoiding boarder effect. The sample plants were harvested separately. The harvested crop of each plot was bundled separately, tagged and taken to threshing floor. The bundles were thoroughly dried in bright sunshine, weighed and threshed respectively.

Data were recorded on days to physiological maturity, days to harvest maturity, number of grains spike-1, 1000-grain weight (g), grain yield (t ha-1), straw yield ( $\mathrm{t} \mathrm{ha}^{-1}$ ) and harvest index. The harvest index (\%) was calculated according to the following formula.

Harvest index (\%)

$$
=\frac{\text { Grainyield }}{\text { Biologicalyield }(\text { grainyield }+ \text { strawyield })} \times 100
$$

The data were complied and subjected to statistical analysis. Analysis of variance was done with the help of MSTAT-C computer package (Russell, 1994). Treatments means were compared for significance by using LSD test at $5 \%$ level of probability. The days to day's maximum and minimum air temperatures ( $\left.{ }^{\circ} \mathrm{C}\right)$, and other weather data were recorded during the wheat growing season and weekly averages were calculated (Fig. 1).

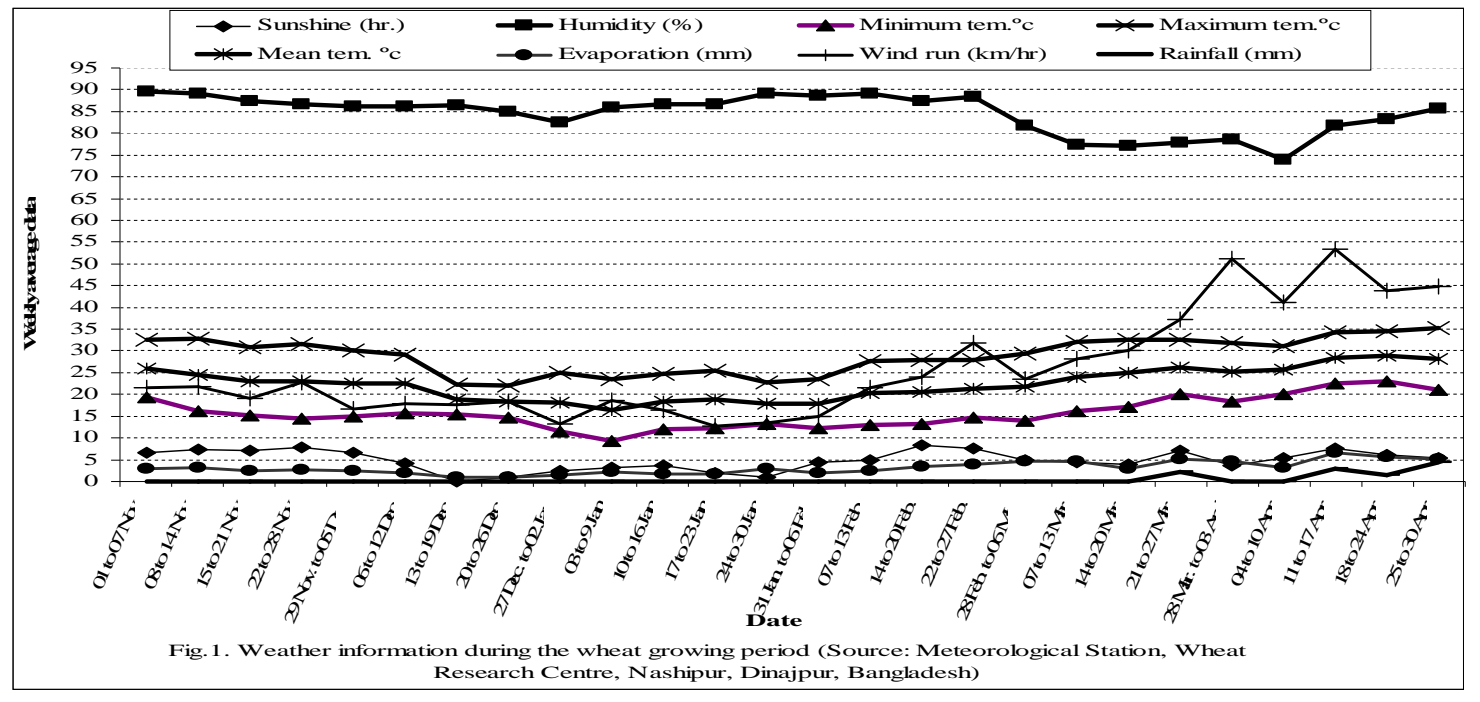




\section{Results and Discussion}

High temperature influenced modification of plant physiological processes. These effects differ from one phonological stage to another. The variations might be due to difference in genetic make-up of the varieties and their interactions with the environment (Islam, 1995).

\section{Weather conditions during wheat growing period}

It is observed from Fig. 1 that crop sown on November 08 and 15, maximum temperature in vegetative stage was near at $\geq 30^{\circ} \mathrm{C}$ and minimum was $\leq 15^{\circ} \mathrm{C}$, but at grain filling stage maximum was $\geq 25^{\circ} \mathrm{C}$ and minimum was 10 to $12^{\circ} \mathrm{C}(27$ December to 20 January). The temperature of vegetative stage in November 08 and 15 sowings are not suitable for good yield, because at vegetative stage maximum temperature was above $30^{\circ} \mathrm{C}$, which affected on stand establishment of crop and tillers production, ultimately poor yield. The result is in accordance with Kumer et al. (1994) and Fischer (1990), who mentioned that in early sown (1st and $2^{\text {nd }}$ week of November) crop got unfavorable environment (high temperature) at vegetative stage as a result crop become thinned and produced less tillers, despite of the heading and grain formation stages is favorable, but the crop did not recover the stress which was got at vegetative stage.

Wheat sown on November 22 to December 20, average maximum temperature in vegetative stage, was near at $25^{\circ} \mathrm{C}$ and minimum was near at $15^{\circ} \mathrm{C}$, but at grain-filling stage average maximum temperature was also near at $25^{\circ} \mathrm{C}$ and minimum was near at 10 to $15^{\circ} \mathrm{C}$, which is suitable for good yield in crop. Chowdhury and Wardlaw (1978) stated that optimum temperature for grain development of wheat lies within the temperature range of $10-15^{\circ} \mathrm{C}$ to $13-18^{\circ} \mathrm{C}$ and with the increase in temperature from $10-21^{\circ} \mathrm{C}$ to $25-30^{\circ} \mathrm{C}$, grain growth is reduced by $38 \%$, as a result, grain size is reduced significantly.

On the other hand in extremely late sowing (December 27) condition, during germination, minimum temperature was very low $\leq 10^{\circ} \mathrm{C}$ and at vegetative stage temperature was maximum $\geq 25^{\circ} \mathrm{C}$ and minimum $\leq 10^{\circ} \mathrm{C}$, but at grain filling stage maximum was $\geq 30^{\circ} \mathrm{C}$ and minimum was $\leq$ 18 to $20^{\circ} \mathrm{C}$ (Mach-April), which was also no suitable for proper growth and good yield. Chowdhry and Wardlaw (1978), Wardlaw and Wrigley (1994) and Stone and Nicolas (1994) reported that moderately high temperatures (25$32^{\circ} \mathrm{C}$ ) and short periods of very high temperatures $\left(33-40^{\circ} \mathrm{C}\right.$ and above) during grain filling severely affect the yield, yield components of wheat and barley. Kumer et al. (1994) also reported that the late crop which was sown on extremely late (last week of December) suffered severely from heat stress during grain formation in March leading to abnormal development and poor production, due to shorten of life span.

\section{Days to physiological maturity}

Days to physiological maturity decreased significantly from early to late sowing. From Fig. 2 , it can be inferred that, all the variety sown on (08 November) need maximum days for physiological maturity as compared to late sowing (27 December). It was noticed that the variety Shatabdi need highest days to physiological maturity in all sowing condition, closely followed by Sourav, Bijoy, BARI Gom-26, Prodip, BARI Gom-25 and minimum days need for variety Sufi and Gourab (Fig.2).

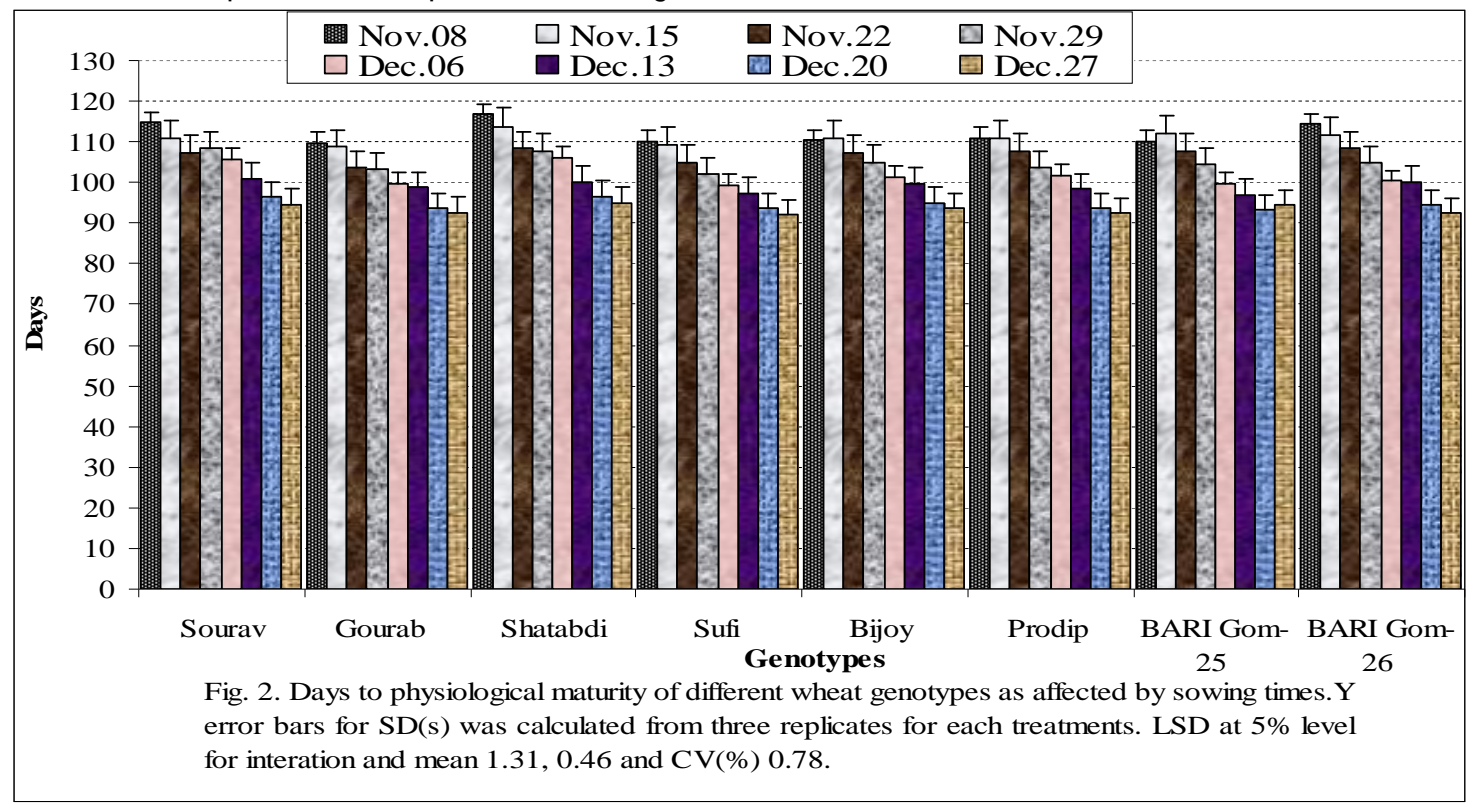


Days to physiological maturity of wheat cultivars also showed a significant variation due to inherent differences between the cultivars (Shahzad et al., 2007). Up to 29 November Gourab need minimum and after 29 November Sufi need minimum days to get physiological maturity. Spink et al. (1993) also observed that delayed sowing shortens the duration of each development phase due to rising of temperature.

\section{Days to harvest maturity}

It is observed in Fig. 3, for sowing dates, that trend of days to harvest maturity in late sown crop is statistically similar as days to physiological maturity in early sown crop. It might be due to decreased temperature from early to optimum than increased optimum to late. As a result, early sowing were maturation late, because of low temperature at grain-filling and maturation time and late sowing needed short time for maturation, due to high temperature at grain-filling and maturation time, which reduced the life span of late sown crop (Fig.1). In all sowing condition, variety Shatabdi need maximum days to get harvest maturity, followed by Sourav and variety Gourab needed minimum, which was statistically followed by cultivars Sufi, Prodip, BARI Gom-25, Bijoy and BARI Gom-26, respectively. Shahzad et al. (2007) reported that Days to harvest maturity of wheat cultivars also showed a significant variation due to inherent differences between the cultivars. On the other variety Shatabdi sown on 08 November needed significantly maximum days to harvest maturity followed by BARI Gom-26. It was noticed that the variety Shatabdi and Sourav needed maximum days to get harvest maturity and variety Gourab needed minimum days to get harvest maturity, except December 27. It was observed that all cultivars sown in early need higher days compared to late sown. Fischer (1990) mentioned that high temperature hastens the development, shortens the duration and reduces the life span of late sowing cultivars from sowing to harvest.

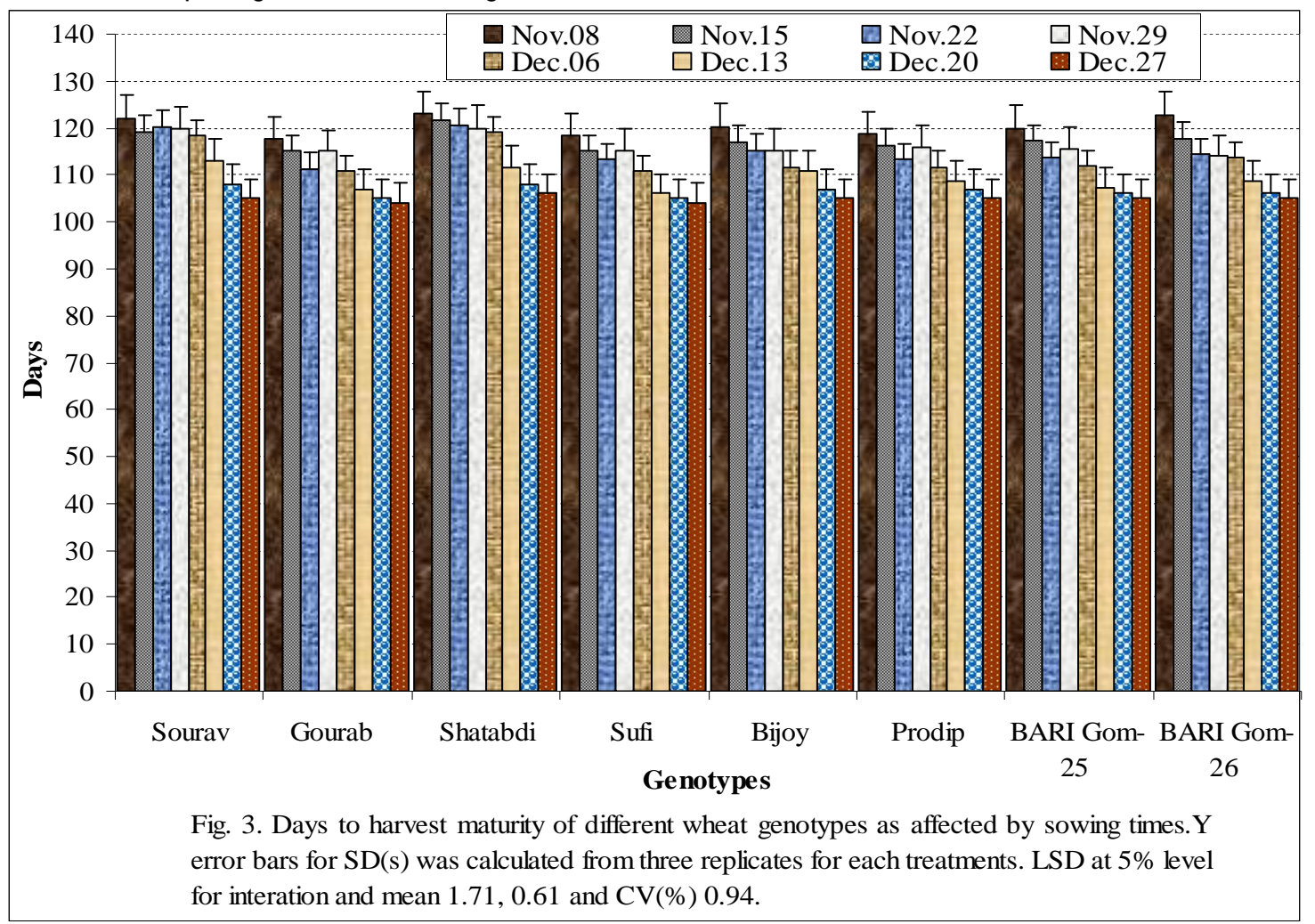

\section{Number of grains per spike}

Number of grains spike ${ }^{-1}$ is very important parameter contributing toward grain yield. Number of grains spike-1 depends on the length of spike and it is determined by genetic make up and environmental factors prevailing during the growth period. Number of grains spike- ${ }^{-1}$ has a direct bearing on the final grain yield in wheat and varies with growing conditions. The crop sown on December 06 produced significantly higher number of grains followed by December 13 and 27, respectively (Fig. 4). The crop sown on December 06 may have enjoyed longer duration and favourable temperature (Fig.1) for growth and development as compared to others and produce maximum number of grains spike ${ }^{-1}$. The results are inconsistent with those of Ali et al. (1982). It is observe from the data in Fig. 4 that lower number of grains spike ${ }^{-1}$ in all variety was 
recorded at early sowing, it might be due to early sowing exposure of the crop to short duration of low temperature at grain filling stage (Fig. 1). These results were similar to those of Haq and Khan (2002) and Shah and Akmal (2002). Incase of cultivars varietals differences regarding number of grains spike ${ }^{-1}$ was probably due to their differences in genetic make up (Islam, 1995). It was noticed that cultivar BARI Gom-26 sown on December 06 produced the highest number of grains spike ${ }^{-1}$ which was statistically similar to December 13, 20 and November 29, Sufi sown on December 06, 13, 20 and 27, Sourav sown on December 06, respectively. The lowest grains spike $^{-1}$ was recorded from cultivar BARI Gom-25 sown on November 15, statistically followed by Gourab sown on November 15, 22, Bijoy sown on 8, 15, 22 and 29, Sourav on November 08, Prodip sown on 8 and 15, and BARI Gom-26 sown on November 08 , respectively. It was observed that most of the cultivars produced higher gains spike- ${ }^{-1}$ sown on December 06 to 27, but in optimum time produced lower grains spike- ${ }^{-1}$ (Fig. 4). It might be due to unfavorable environment at floret formation and grain filling stage. It was observed from fig. 1 that temperature was very high from emergence to double ridges stage (GSI) of crop, which effect on floret formation, resulted lower grain spike ${ }^{-1}$ in early sowing crops. OToole and Stockle (1991) reported that the sensitivity to high temperature increases as vegetative growth develops and tillering proceeds towards the end of GSI (Emergence to double ridges) stage. The sensitivity to high temperature during this phase is expressed as decreased duration of GS1 (Shpiler and Blum, 1986) and reduced leaf area and growth. Reduction in total number of leaves and spike bearing tillers is also an effect of high temperature during this phase (Midmore et al., 1984). Owen (1971) and Saini and Aspinal (1982) reported that temperatures above $30^{\circ} \mathrm{C}$ during floret formation cause complete sterility, ultimately reduced grains spike ${ }^{-1}$.

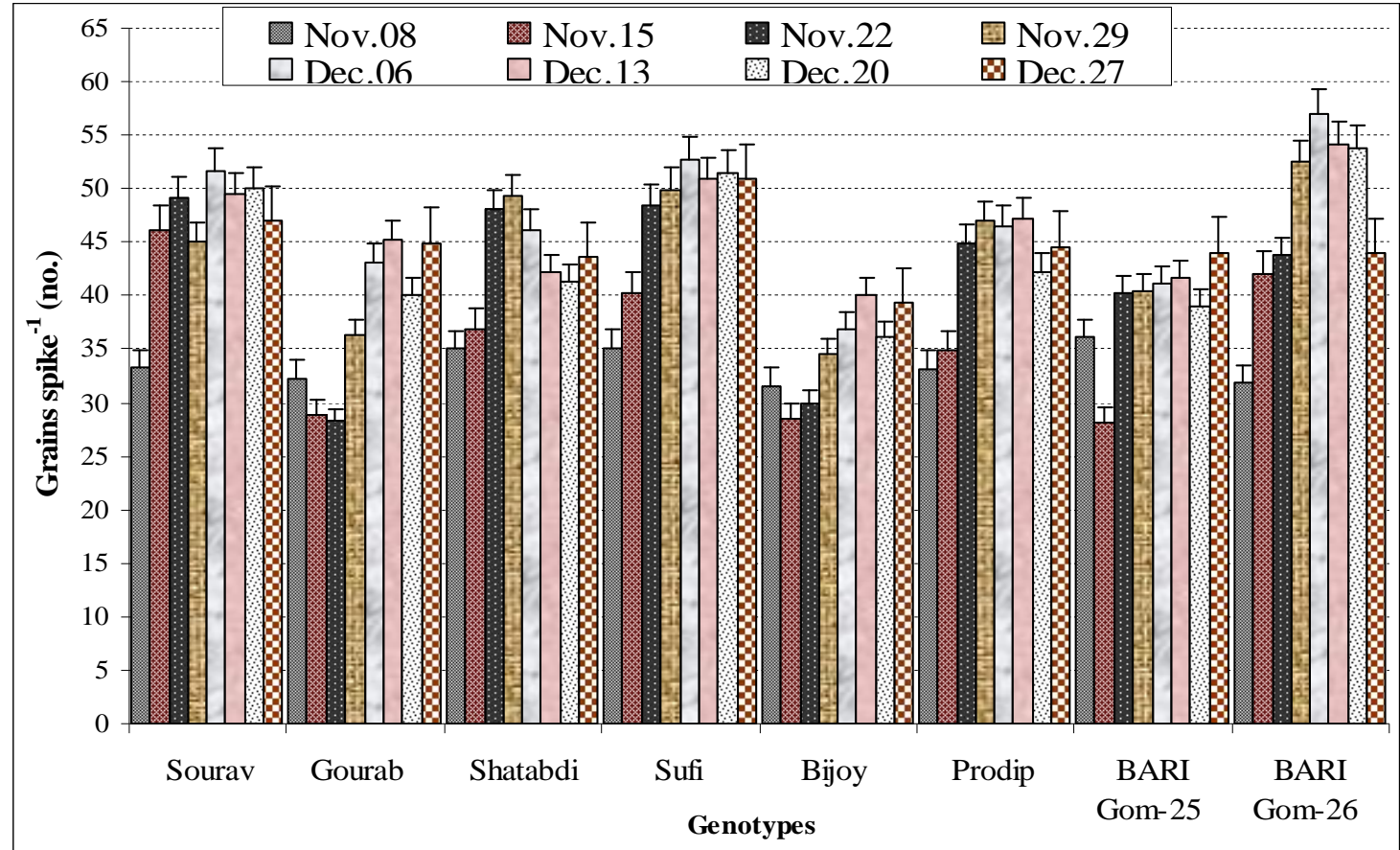

Fig. 4. Grains spike ${ }^{-1}$ of different wheat genotypes as affected by sowing times. Y error bars for $\mathrm{SD}(\mathrm{s})$ was calculated from three replicates for each treatments. LSD at $5 \%$ level for interation and mean 6.74, 2.38 and $\mathrm{CV}(\%) 9.88$.

\section{0 grain weight}

Delayed sowing shortens the duration of each development phase, which ultimately reduces grain filling period and lowers the grain weight (Spink et al., 2000). A subsequent decrease in 1000 grain weight in wheat with delayed sowing was reported by Joarder et al. (1981). In our present study, it was noticed that November 22 and 29 sowing produced the statistically higher 1000-grain weight and December 27 sowing produced the lowest 1000-grain weight (Fig. 5). It might be due to favourable temperature at growth stage of crop, especially grain filling stage of November 22 and 29 sown crops (Fig.1). On the other hand at extremely late sowing (December 27), temperature was very high at grain filling stage which ultimately reduced the grain yield of the crop due to shortens of each development phage. Spink et al. (2000) also observed that delayed sowing shortens the 
duration of each development phase which ultimately reduces grain filling period and lowers the grain weight. Considering on cultivars highest 1000-grain weight was recorded from Prodip, followed by BARI Gom-25, Bijoy, Gourab, BARI Gom-26, Shatabdi, Sourav and Sufi, respectively. Variety Prodip sown on November 29 produced the highest 1000-grain weight. It was observed variety Prodip produced highest 1000-grain weight in all sowing dates except December 20 and 27 and the lowest 1000-grain weight was recorded from variety Sufi in all sowing dates. It was also noticed that optimum sowing produced higher 1000-grain weight than late sowing (Fig.5). The early sowing resulted in better development of the grains due to longer growing period. Similar results was also found by Sofied et al. (1977), they reported that higher grain weight was observed due to favourable temperature associated with longer grain filling period. Lower 1000-grain weight was found in late sowing (December 20, 27), due to high temperature at growth stage, especially in grain filling stage. These findings are strongly supported by those of Spink et al. (2000) and Shahzad et al. (2002) who had also reported decreased 1000-grain weight with delay in sowing. Similar results have been reported in the past (Qamar et al., 2004; Subhan et al., 2004).

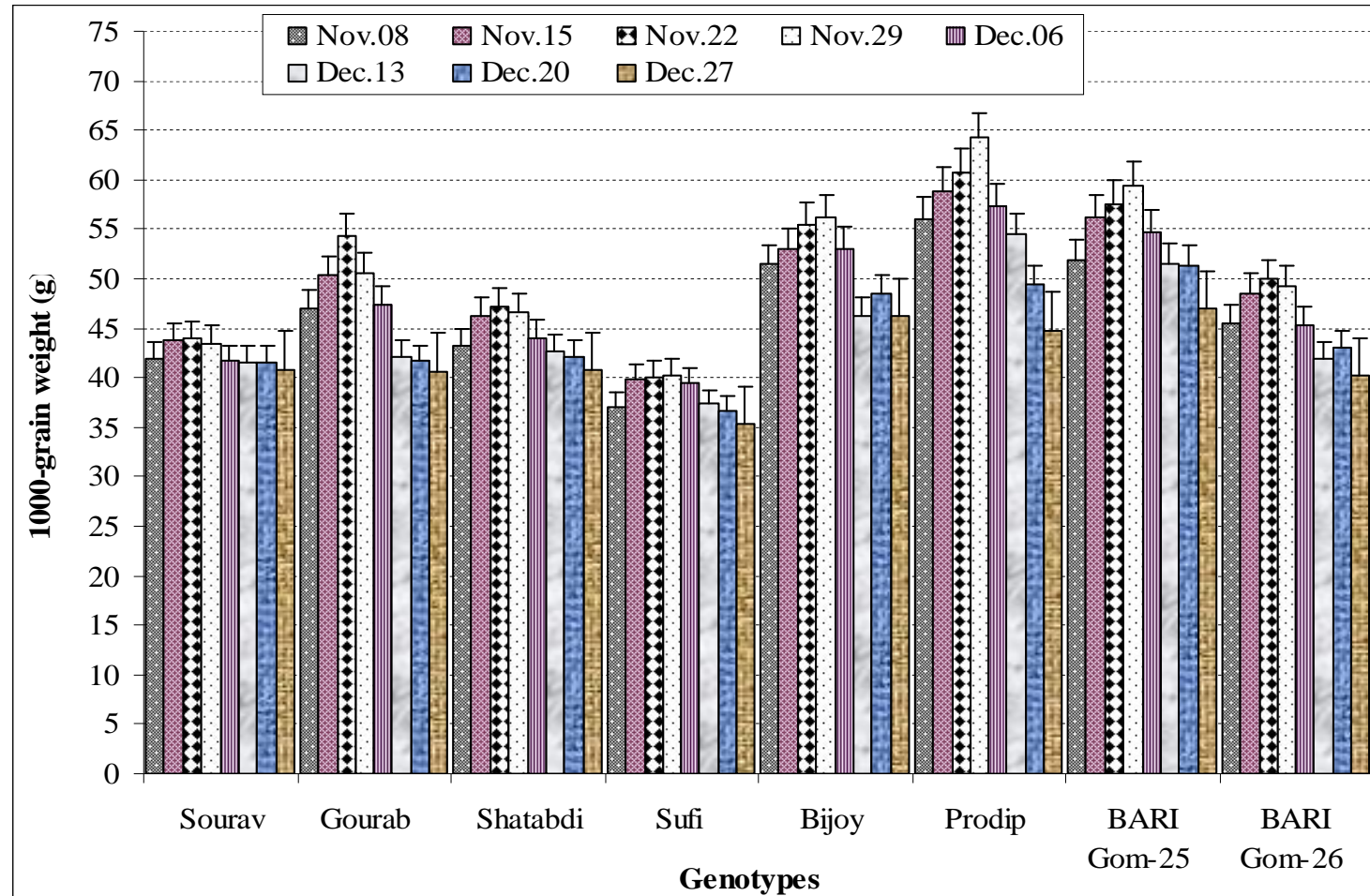

Fig. 5. 1000-grain weight of different wheat genotypes as affected by sowing times.Y error bars for SD(s) was calculated from three replicates for each treatments. LSD at $5 \%$ level for interation and mean 2.0, 0.71 and CV(\%) 2.62.

\section{Harvest index}

Singh et al. (1990) and Sharma and Singh (1991) stated that harvest index is the important traits for selecting high yielding genotypes under normal and late planting condition. High harvest index, which is indicative of efficient utilization of photosynthates, was also associated with high yields under the stress condition (Gifford et al., 1984; Blum et al., 1994). In our present research, it was found that interaction between dates of sowing and genotypes were significantly influenced for harvest index. Cultivar BARI Gom26 sown on November 08 15, 22, 29 and
December 06, cultivar Sourav Sown on November 08, 29; Gourab sown on November 08, 29 and December 27; Shatabdi sown on December 27 and BARI Gom-25 sown on November 08 and 22 produced statistically similar higher harvest index. Minimum harvest index was recorded from cultivar Shatabdi sown on November 15 (Fig. 6). Ferris (1998) reported that grain yield and harvest index also declined sharply with maximum temperature $\left(31^{\circ} \mathrm{C}\right)$ at 78 DAS. It was found that, the variety which has higher harvest index has higher biomass and has lower grain yield. 


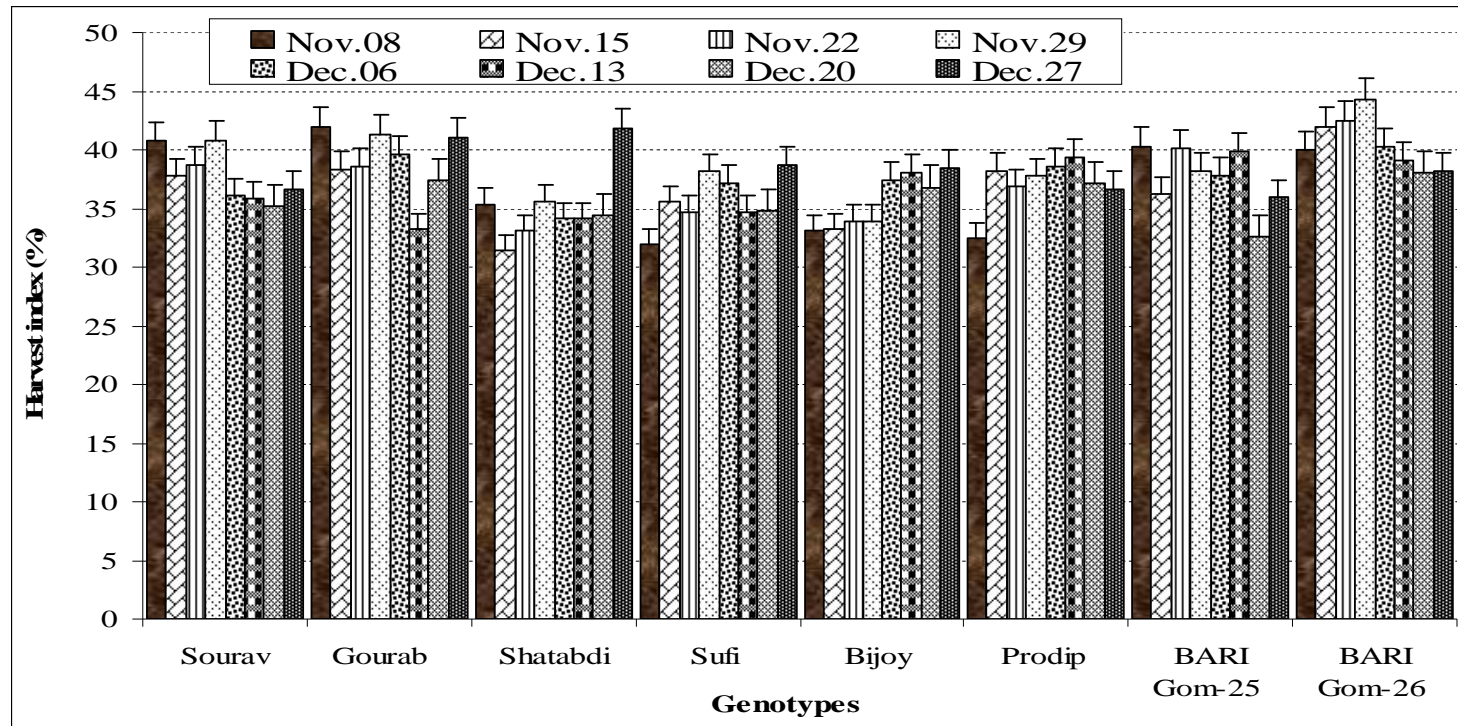

Fig. 6. Harvest index (\%) of different wheat genotypes as affected by sowing times. Y error bars for $\mathrm{SD}(\mathrm{s})$ was calculated from three replicates for each treatments. LSD at $5 \%$ level for interation and mean $4.50,1.59$ and $\mathrm{CV}(\%) 7.45$.

\section{Straw y ield}

The data revealed that straw yield was significantly affected by cultivars sown on different times (Fig. 7). The crop sown on November 22 to December 20 produced statistically similar straw yield. The lowest was recorded from variety Sourav, followed by Gourab and BARI Gom-26. Considering on cultivars the highest was recorded from variety Shatabdi. Cultivars Bijoy, Sourav, Sufi and Prodip produced statistically similar $2^{\text {nd }}$ highest straw yield and BARI Gom-26, BARI Gom-25 and Gourab produced statistically similar $3^{\text {rd }}$ highest straw yield. Cultivar Shatabdi sown on November 22 produced the highest straw yield which was similar to November 29 and December 06 (Fig.7). Donaldson et al. (2001) reported that early sowing resulted in higher straw yield due to more number of tillers. These results are in agreement with those of Matuz and Aziz (1991). The lowest was recorded from BARI Gom-26 sown on November 08 , followed by Gourab and BARI Gom-25 sown on November 08. It might be due to high temperature at vegetative stage (Fig.1). Kumer et al. (1994) reported that the straw yield decreased probably due to the fact that plant got unfavorable environment (high temperature) at vegetative stage, as a result crop became thinned and produced less tillers which in turn decreased the straw yield.

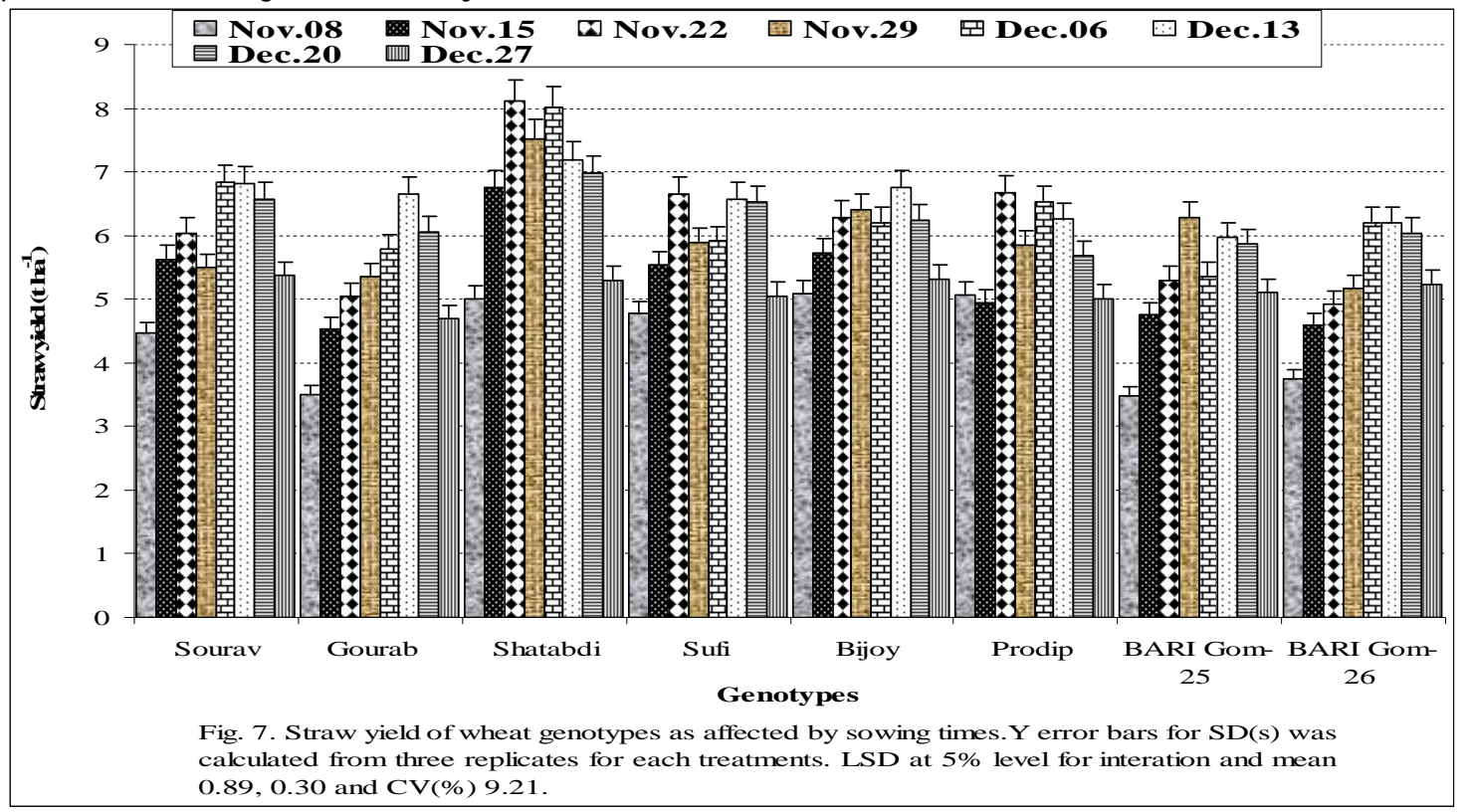




\section{Grain yield}

Heat stress extended the duration of grain filling with reduction in kernel growth leading to losses in kernel density and weight by up to $7 \%$ in spring wheat (Guilioni et al., 2003). Wahid et al. (2007) found that excess radiation and high temperatures are the most limiting factors affecting plant growth and finally crop yield in tropical environment. Sing et al. (1986) found that grain yield of barley decreased at delayed sowing from 10-25 December and $10 \mathrm{~J}$ anuary.

Grain yield was significantly influenced by sowing dates in respect of cultivars. Crop sown on December 06 was the highest grain yield, which was statistically similar to December 13, November 29 and 22 sowing. The second highest grain yield was December 20 sowing and the lowest was recorded November 08 sowing followed by November 15 and December 27 sowing. It was observed at early sowing (November 08 and 15) and at extremely late sowing (December 27) that produced lower yield

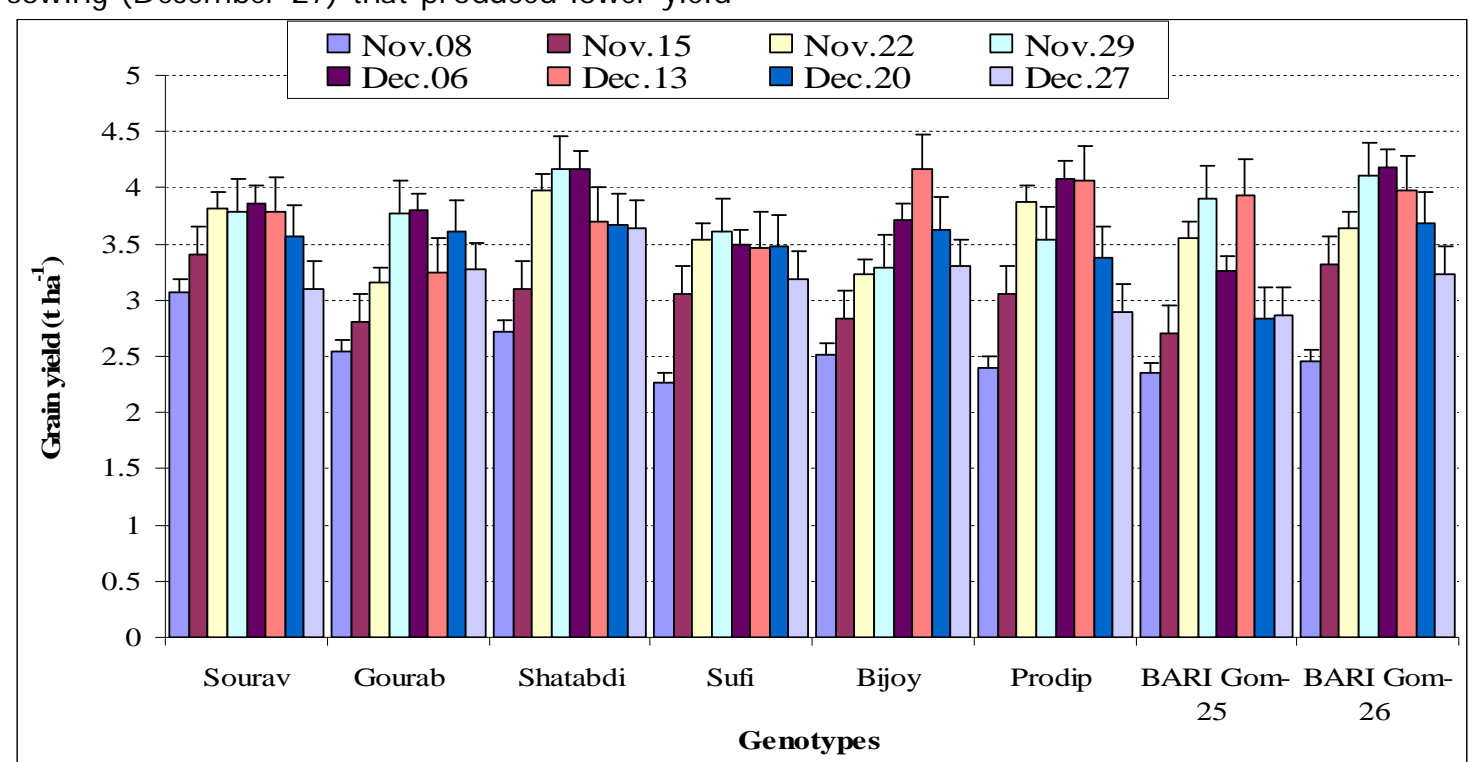

Fig. 8. Grain yield of wheat genotypes as affected by sowing times.Y error bars for SD(s) was calculated from three replicates for each treatments. LSD at $5 \%$ level for interation and mean $0.47,0.17$ and $\mathrm{CV}(\%) 8.62$.

In the present research, in high temperature stress in too early (08 November) and very late (27 December) sowing condition the yield reduction was 20.47 and $19.69 \%$ in Sourav, 33.16 and $13.95 \%$ in Gourab, 34.62 and $12.50 \%$ in Shatabdi, 34.96 and $8.60 \%$ in Sufi, 32.08 and 11.05 in Bijoy, 41.18 and 28.92\% in Prodip, 27.91 and $11.96 \%$ in BARI Gom-25 and 41.15 and $22.73 \%$ in BARI Gom-26, respectively as compared to December 06 (high yield). In extremely heat stress (November 08 and December 27) condition Prodip was found to be heat sensitive genotype (yield reduction 41.18 and $28.92 \%)$, followed by BARI Gom-26 (41.15 and $22.73 \%)$. On the other hand genotype Sourav and than other sowings, it might be due to high temperature stressed vegetative growth of early two sowing and grain filling stage of extremely late sowing (Fig. 8). It was noticed that the cultivar Shatabdi produced the highest grain yield, closely followed by BARI Gom-26 and Sourav. The second highest grain yield was resulted from Prodip, which was statistically similar to Bijoy, Gourab and Sufi and the lowest was recorded from BARI Gom-25. Cultivar Shatabdi produced statistically higher grain yield across all the sowing dates with little exception, which was similar to BARI Gom-26, Sourav, while cultivar BARI Gom-26 produced the lowest grain yield across all sowing dates. It was noticed that more than $3 \mathrm{t} \mathrm{ha}^{-1}$ yield was recorded from cultivar Sourav in all sowing dates. All the cultivars sown on November 08, 15 and December 27 (extremely late) produced comparable lower yield than others, it might be due to unfavorable growing condition at these sowing dates.
BARI Gom-25 was found to be heat tolerant as compared to yield reduction in both too early and very late sowing condition. In very early (November 08) sowing condition Sourav (yield reduction $20.47 \%$ ) is recommended, followed by BARI Gom-25 (27.91\%) and in very late (December 27) condition Sufi is the best (yield reduction $8.60 \%$ ), followed by Bijoy (yield reduction11.05\%). Hasan (2002) stated that grain yield reduction was 2.6 to $5.8 \%$ in heat tolerant and $7.2 \%$ in heat sensitive genotypes for each $1^{\circ} \mathrm{C}$ rise in average mean air temperature from optimum condition during anthesis to maturity. 


\section{Conclusion}

It can be concluded that grain yield and its components were affected considerably by sowing date. The results showed that wheat sown in November 22 to December 20 was significantly better compared to November 08, 15 and December 27 sowings for the studied aspects of growth and yield. The thermal time required by wheat to reach maturity was nearly constant irrespective of temperature and date of sowing. It is, therefore, recommended that the crop should be sown by November 22 to December 20. Considering overall sowing performance of all genotypes variety Shatabdi is the best, followed by BARI Gom-26 (2nd), Sourav (3rd), Prodip (4th), Bijoy (5th), Gourab (6th), Sufi (7th) and BARI Gom-25 (least). Variety Sourav and BARI Gom-25 were found to be heat tolerant as compared to yield reduction in both too early (November 08 ) and very late (December 27) condition. Only in very early sowing condition (November 08) Sourav is first recommended, followed by BARI Gom-25 and in very late (December 27) condition Sufi is first recommended, followed by Bijoy.

\section{Acknowledgements}

We are most grateful to the staff of the Wheat Research Center, Bangladesh, for maintaining the experimental plants. Financial support from Director General of Bangladesh Agricultural Research Institute is also gratefully acknowledged.

\section{References}

Ahmed, S.M. 1986. An overview of wheat research and development in Bangladesh. $3^{\text {rd }}$ National Wheat Training Workshop. August 4-5, 1986. Wheat Res. Cent., Bangladesh Agril. Res. Inst., Dinajpur.

Ali, G., Iqbal, Z. and Nazir, M.S. 1982. Grain yield and protein contents of some short duration wheat genotypes in relation to degree of late sowing. Pakistan J. Agric. Res., 20: 9-16.

Ansary, A.H., Khushak, A.M., Sethar, M.A., Ariam, N.A. and Emon, M.Y.M. 1989. Effect of sowing dates on growth and yield of wheat cultivars. Pakistan J. Sci. Ind. Res., 32: 3942.

BARI(Bangladesh Agricultural Research Institute). 1990. Annual Report, 1989-90. Bangladesh Agricultural Research Institute, Gazipur, Bangladesh

Blum, A., Sinmena, B., Mayer, J., Golan, G. and Shpiler, L. 1994. Stem reserve mobilization supports wheat-grain filling under heat stress. Australian J. Plant Physiol., 21: 771781.

Badruddin, M., Saunders, D.A., Siddique, A.B., Hossain, M.A. Ahmed, M.O., Rahman, M.M. and Parveen, S. 1994. Determining yield constraints for wheat production in Bangladesh. In: Wheat in Heat Stressed Environments; Irrigated, Dry Areas and Rice-Wheat Farming systems (Eds. D. A. Saunders \& G. P. Hettel) pp. 265-271. CIMMYT, Mexico.

Boduzzaman, M., Lauren, J.G., Duxbury, J.M., Sadat, M.A., Welch, R.M., Elahi, M.E. and Meisner, C.A. 2005. Increasing wheat and rice productivity in the sub-tropics using micronutrient enriched seed. In Micronutrients in South and South-east Asia. (Eds.) by Anderson P., K. Junoo, Tuladhar, B. Krishna, Karki and LM. Surya; Proc. of an Proc Int. Workshop, held at 8-11 Sept, 2005, Kathmandu, Nepal. pp. 187198.

Chowdhury, S.I. and Wardlaw, I.F. 1978. The effects of temperature on kernel development in cereals. Australian J. Agric. Res., 29: 205-223.

Dabre, W.M., Lall, S.B. and Lngole, G.L. 1993. Effects of sowing dates on yield, ear number, stomatal frequency and stomatal index in wheat. J. Maharashatra Agril. Univ., 18: 64-66.

Donaldson, E., Schillinger, W.F. and Dofing, S.M. 2001. Straw production and grain yield relationship in winter wheat. Crop Sci., 41: 100-106.

Ferris, R. 1998. Effect of High Temperature Stress at Anthesis on Grain Yield and Biomass of Field-grown Crops of Wheat. Ann. Bot., 82(5): 631-639.

Fischer, A.S. 1990. Physiological limitation to producing wheat in semi-tropical and tropical environment and possible selection criteria. Wheats for More Tropical Environments. Proc Int. Symp., Sept. 2428, CIMMYT, Mexico.

Gifford, R.M. and Thorne, J.M. 1984. Crop productivity and photo-assimilate partitioning. Science, 225: 801-807.

Guilioni L., Wery, J. and Lecoeur, J. 2003. High temperature and water deficit may reduce seed number in field pea purely by decreasing plant growth rate. Functional Pl. Biol., 30: 1151-1164.

Haq, N.U. and Khan, M. 2002. Effect of planting date, chlortoluran + MCPA and wheat varieties on weed control and wheat yield. Sarhad J . Agric., 18: 443-447.

Hasan, M.A. 2002. Physiological changes in wheat under late planting heat stress. M.S thesis. Dept. Crop Botany. Bongabandu Sheikh Mujibur Rahman Agril. Univ., Salna, Gazipur, Bangladesh.

Hossain, M.A. and Alam, N. 1986. Effect of date of sowing and seed rate on the yield on wheat (var. Kanchan) under irrigated condition in Bangladesh. Abst. Bangladesh 
Soc. Agron. conf., held in Bangladesh Agril. Res. Inst., Gazipur.

Islam, M.A. 1995. A study on the Competitive ability of six varieties of wheat with weeds. Bangladesh Agril. Univ., Dept. Agron, MS Thesis, pp. 30-33.

J oarder, O.I., Islam, R., Rahman, S. and Eunus, A.M. 1981. Effect of seeding date on yield of other agronomic trials of some wheat varieties grown on irrigated lands in Bangladesh. Indian J . Agril. Sci., 51(7): 489463.

Kumer, R., Madan, S. and Yunus, M. 1994. Effect of planting date on yield and quality of durum wheat varieties. Res. J. Haryana Agric. Univ., 24: 186-188.

Matuz, J. and Aziz, J.S. 1991. The effect of sowing season on Iraqi and Hungarian wheat varieties. Cereal Res. Commun., 18: 41-43.

Midmore, D.J ., Cartwright, P.M. and Fischer, R.A. 1984. Wheat in tropical environments. II. Crop growth and grain yield. Field Crops Res., 8: 207-227.

O'Toole, J.C. and Stockle, C.D. 1991. The role of conceptual and simulation modelling in plants breeding. In E. Acevedo, E. Fereres, C. Gimenez and J.P. Srivastava, eds. Improvement and Management of winter Cereals under Temperature, Drought and Salinity Stresses. National Institute for Agricultural Research, (INIA), Madrid, Spain.

Owen P.C. 1971. Responses of semi-dwarf wheat to temperatures representing a tropical dry season. II. Extreme temperatures. Expt. Agric., 7: 43-47.

Phadnawis, B.N. and Saini, A.D. 1992. Yield models in wheat based on sowing time and phenological developments. Ann. Pl. Physiol., 6: 52-59.

Qamar, M., Ullah, S. and Makeen, S. 2004. Genetic variability among wheat cultivars and effect of planting date on grain and straw yield under double cropping zone of Northern areas of Pakistan. Sarhad J. Agric., 20: 99-102.

Rajput, R.L. and Verma. 1994. Effect of sowing dates on the yield of different varieties of wheat in Chambal Command Area of Madhya Pradesh Bharyiya Krishi Anusandhan Patrika. Indian J. Agron., 9: 165-169.

Russell O.F. 1994. MSTAT-C v.2.1 (a computer based data analysis software). Crop and Soil Science Department, Michigan State University, USA.

Saini, H.S. and Aspinal, D. 1982. Abnormal sporogenesis in wheat (Triticum aestivum L.) induced by short periods of high temperature. Ann. Bot., 49: 835-846.
Saunders, D.A. 1991. Report of an on farm survey "Jessore and Kustia" Wheat farmers practices BARI, Nashipur, Dinajpur, Monograph No. 8. 30p.

Shah, M.S.S. and Akmal, M. 2002. Effect of different sowing dates on yield and yield components of wheat varieties. Sarhad J. Agric., 18: 143-149.

Shahzad, K., Bakht, J., Shah, W.A., Shafi, M. and Jabeen, N. 2002. Yield and yield components of various wheat cultivars as affected by different sowing dates. Asian J . Plant Sci., 1(5): 522-525.

Shahzad, M.A., Wasi-ud-Din, Sahi, S.T., Khan, M.M., Ehsanullah and Ahmad, M. 2007. Effect of sowing dates and seed treatment on grain yield and quality of wheat. Pakistan J . Agril. Sci., 44: 581-583.

Sharma, S. C. and Singh, I. 1991. Path coefficient analysis of harvest index and its related traits in bread wheat. Haryana J. Agron., 7: 49-55.

Shpiler, L. and Blum, A. 1986. Differential reaction of wheat cultivars to hot environments. Euphytica, 35: 483-492.

Singh, V.P.N. and Uttam, S.K. 1999. Influence of sowing dates on yield of wheat cultivars under saline sodic conditions in Central Utter Pradesh. Indian J . Agric., 38: 64-68.

Singh, J., Malik, A.S. and Singh, J. 1986. Response of late-sown wheat, barley and lentil to irrigation levels. Haryana J. Agron., 5: 52-56.

Singh, I., Paroda, R.S. and Sharma, S.K. 1990. Studies on association of total biomass with yield and its components in wheat. Haryana Agric. Univ. J. Res. India, 20: 3539.

Sofied, I.L., Evans, T., Cook, M.G. and Wardlaw, I.F. 1977. Factor influencing the rate and duration of grain filling in wheat. Australian J. Physiol., 4: 785-797.

Spink, J.H., Semere, T., Sparkes, D.L., Wahley, J.M., Foulkes, M.J., Calre, R.W. and Scatt, R.K. 2000. Effect of sowing dates and planting density of winter wheat. Ann. App. Biol., 137(2): 179-188.

Spink, J.H., Clare, R.W. and Kilpatricks, J.B. 1993. Grain quality of milling wheat at different sowing dates. App. Biol., 36: 231240.

Stone, P.J. and Nicolas, M.E. 1994. Wheat cultivars vary widely in their responses of grain yield and quality to short periods of post anthesis stress. Australian J. Plant Physiol., 21: 887-900.

Subhan, F., Khan, M., and Jamro, G.H. 2004. Effect of different planting date, seeding rate and weed control method on grain yield and yields components in wheat. Sarhad J. Agric., 20: 51-55. 
Wahid, A., Gelani, S., Ashraf, M. and Foolad, M.R. WRC (Wheat Research Center). 2007. Annual 2007. Heat tolerance in plants: An overview. Report, 2006-07, Wheat Res Cen., Environ. Expt. Bot., 61: 199-233.

Wardlaw, I.F. and Wrigley, C.W. 1994. Heat Nashipur, Dinajpur, Bangladesh. p. 26, 51. tolerance in temperate cereals. An overview. Australian J. Plant Physiol., 21: 695-703. 